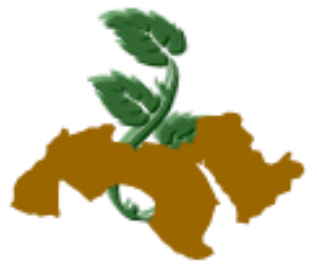

\title{
FARMERS' BEHAVIORAL INTENTIONS TO USE MOBILE EXTENSION IN ASSIUT GOVERNORATE
}

\author{
Abdel-Ghany M.M.M. \\ Department of Rural Sociology \& Agricultural Extension, Faculty of Agriculture, \\ University, Assiut, Egypt \\ Assiut \\ E-mail: mohamed.abdelghani@agr.au.edu.eg
}

Keywords: Behavioral Intentions, Mobile Extension, Multiple Regression Analysis

\section{ABSTRACT}

Sixteen flax genotypes $\{13$ promising lines This study aimed at: (1) knowing about farmers' views about advantages, disadvantages of mobile extension service and their suggestions to make this prospective initiative succeed; (2) discovering farmers' behavioral intentions to use mobile extension service in Assiut governorate; (3) determining the kind of information that farmers will need by using mobile extension service; (4) examining the effect of the six antecedents proposed by Nysveen et al (2005a) on farmers' behavioral intentions to use mobile extension service. Data were collected by questionnaire from 233 farmers randomly selected from two villages in Assiut governorate. The results showed the advantages, disadvantages of mobile extension service from the viewpoint of the respondents and their suggestions to make this prospective initiative succeed. It came out that the respondents have positive intentions to use mobile extension, and their prospective behavior proceeds to use mobile extension service if it comes into existence. It cleared up that the information needs of farmers by using mobile extension were related to market information (prices, and demand indicators) and know-how information (what to plant and which seed varieties to use). It be- came clear that the model of Nysveen et al (2005a) was overall significant and the six antecedents of behavioral intentions significantly explains $71 \%$ of variance in farmers' behavioral intentions to use mobile extension service. Finally, based on the results of this study, major recommendations are derived for the potential producers when developing the prospective mobile extension service

\section{INTRODUCTION}

Farming is becoming a more time-critical and information-intense business. A push towards higher productivity will require an information-based decision-making agricultural system. Farmers must get information at the right time and place (Brugger, 2011). Mobile phone penetration has been growing rapidly even in rural areas. The speed of adoption of mobile phone technology has raised the general expectations about its potential contributions to spread of innovative farming technology, as well as farmers' knowledge and awareness of other relevant knowledge and information (Fu and Akter, 2011).

During the past two decades, there has been a revolution in ICTs, with mobile phones becoming a key tool for transmitting knowledge and market information to farmers (Pye-Smith, 2012). The rapid growth of mobile telephony in developing countries has introduced a new technology that offers several advantages over other alternatives in 
terms of cost, geographic coverage and ease of use. This not only provides new opportunities for rural farmers to obtain access to information on agricultural technologies, but also to use ICTs in agricultural extension services (Aker, 2011). As a telephonic device, the mobile enables access to information sources that may not otherwise be reachable. As information platform to receive SMSs, menu or voice messages, mobiles provide the ability to get connected to new knowledge and information sources not previously available with the possibility of real-time, highly tailored information delivery (Mittal et al 2010).

With regard to emerging information technologies like mobile applications, individual's behavior for predictive purposes has been widely discussed recently. One of the most commonly used models is behavioral intentions (BI) model. This model assumes that behavior toward a particular object is determined by an intention to perform that behavior (Malhotra and McCort, 2001). Punnoose (2012) quoted from Ajzen and Fishbein (1980) that intention is an indicator used to capture the factors that influence a desired behavior. Behavioral intention is the cognitive representation of a person's readiness to perform a given behavior, and it is considered to be the immediate antecedent of behavior. Behavioral intention indicates how much effort an individual would like to commit to perform such behavior. Higher intention is more likely to mean that behavior would be performed.

In June 2011, a pioneering initiative for using mobile in Egyptian agricultural extension was announced by a cooperation protocol among the Ministry of Agriculture and Land Reclamation, Vodafone Egypt and Quick Serve. The project is designed to provide farmers with agricultural news and information using SMS, in addition to contacting with the specialists in the agricultural research center through direct calls, SMS and voice messages (Central Administration for Agricultural Extension, 2011). The Protocol avails agricultural extension services via mobile starting from cultivation to harvesting as well as providing the framework for launching a call center for Egyptian farmers. The Center will provide specialized guidance to Egyptian farmers through the ARC, in cooperation with Quick Serve (Vodafone Egypt, 2011). Ac- cording to the agricultural extension manager in Assiut governorate and the respondents of this study, the above mentioned services are not provided yet, and the initiative is not executed practically till now as it has been announced. So, it's obvious that mobile extension represents a potential change in the way agricultural extension in Egypt provides its services, and it's very important to assess farmers' behavioral intentions to use it in order to predict their prospective behavior.

As an attempt to predict farmers' prospective behavior towards mobile extension, this study endeavors to reach the following aims:

1. To know about farmers' views about advantages, disadvantages of mobile extension service and their suggestions to make this prospective initiative succeed.

2. To discover farmers' behavioral intentions to use mobile extension service in Assiut governorate.

3. To determine the kind of information that farmers will need by using mobile extension service.

4. To investigate the effect of the six antecedents proposed by Nysveen et al (2005a) on farmers' behavioral intentions to use mobile extension service.

\section{LITERATURE REVIEW}

\section{Behavioral Intentions}

Wong et al (2013) reported that there are several theoretical models for studying behavioral intentions with regard to emerging information and communication technologies. Among those models, the technology acceptance model (TAM) is considered an influential model for explaining behavioral intentions. The TAM explained that a person's performance of specified behavior was determined by his or her behavioral intention to perform that behavior. There were two specific variables, perceived usefulness and perceived ease of use, which were hypothesized to be the fundamental determinants of a user's acceptance (Davis, 1989).

Studies pertaining to individuals' intentions to use mobile services have been conducted on the basis of Davis's (1989) technology acceptance model (TAM). Although the TAM is very useful in explaining behavioral intentions, several extensions of the model may be 
relevant to explain intentions to use mobile services. It has been suggested that, the TAM may be too parsimonious and omits variables that may be important predictors of behavioral intentions (Venkatesh and Davis, 2000).

Sendecka (2006) reported that Nysveen et al (2005a) provided a more general perspective for discovering what drives individuals' intentions to use a technology; they suggested several extensions that may be relevant in explaining individual's intention to use mobile services by integrating different models together to better predict adoption of mobile services.

The final model of Nysveen et al (2005a) includes the following intentions determinants: perceived expressiveness (3 items), perceived enjoyment (4 items), perceived usefulness (3 items), perceived ease of use (4 items), perceived normative pressure (3 items), and perceived behavioral control (3 items) in addition to behavioral intention (2 items). Nysveen et al (2005) and Nysveen et al (2005b) presented the definitions of their model of behavioral intentions to use mobile services starting with behavioral intentions definition as "a person's perceived likelihood or probability that he or she will perform a specified behavior", then they list intentions determinants as follows:

1. Perceived expressiveness: the degree to which a person perceive the service as suitable for expressing his social or personal identity.

2. Perceived enjoyment: the extent to which the activity of using the service is perceived to be enjoyable in its own right, apart from any performance consequences that may be anticipated.

3. Perceived usefulness: the degree to which a person believes that using the service would enhance his or her performance.

4. Perceived ease of use: the degree to which a person believes that using the service would be free of efforts.

5. Perceived normative pressure: the person's perception that most people who are important to him think he should or should not use the service.

6. Perceived behavioral control: the person's perception of the presence or ab- sence of the requisite resources or opportunities necessary for using the service.

\section{Mobile Extension}

Mobile phones have many key advantages like they are: owned by more people, provide delivery in an instant, more convenient way, can deliver personalized information to individual owners, cheaper to provide other functions such as voice communication, reduce the cost of information and communication, enable both audio and video functions which can meet most of the basic needs of the poor, have greater affordability than the internet and they also offer opportunities to access new sources of information (Fu \& Akter, 2011 and Fielding \& Ninsiima, 2012).

Mobile phone technology has been diffused rapidly in the rural areas of the developing countries in recent years. Mobile phones are being used to help raise farmers' incomes, making agricultural marketing more efficient, lowering information costs, reduce transport costs, provide a platform to deliver services and innovations, increase access to information via agricultural extension services, increase communication linkages with research systems, and increase access to public and private information sources (The World Bank, 2011 and Aker, 2011).

Brugger (2011) and Fielding \& Ninsiima (2012) mentioned some considerations to be considered for using mobile phones in agriculture like: farmers' trust, right price, language barriers, literacy barriers (both general and technical), availability, skills and education level of prospective users, training and support requirements, time to learn and use, richness and value of content provided, content generation and development over time, and responsiveness to user demands.

Mobile phones can improve access to and use of information about a variety of topics at each stage of the agricultural production process. Information needs of farmers through the agricultural cycle can be classified into three categories (Mittal et al 2010) as follows:

1. Know-how information, which helps a farmer with fundamental information such as what to plant and which seed varieties to use. 
2. Contextual information such as weather, plant protection, best practice for cultivation and inputs.

3. Market information such as prices, and demand indicators.

Qiang et al (2012) presented a report about mobile applications for agriculture and rural development (m-ARD apps); their report involved the findings of 15 detailed case studies in Kenya, the Philippines, and Sri Lanka. There have been subsectors of the mobile applications studied including agricultural extension, resource management, labor migration \& human development, governance/ political issues and rural finance \& ICT. The agricultural extension cases studied enclosed Kenya (Provides extension information and advice from a database using SMS or from experts by phone calls within one day), the Philippines (Innovative SMS-based service for answering agricultural queries from farmers and extension workers), and Sri Lanka (Provides farmers with information and access to just-in-time veterinary services using SMS). There were many benefits of the various mobile applications like: increased income through better access to information and services including extension services, better access to finance, higher-yield production, and better market links between farmers, suppliers, and buyers.

The previous report also identified four main pricing models for m-ARD apps: nonchargeable (services are totally free), transactional (charges based on the number of transactions conducted), embedded services (services are provided free of charge by large companies to sell their primary product or service), and freemium (charging is for advanced, value added, specialized services). The report also found that m-ARD apps rely on government, donors, and private sector for startup and operating costs. The financing gap is particularly wide between the pilot stage and stage 1 (sustainability) and during the transition from donor funding (usually limited to the pilot stage) to commercial or governmental funding. While there was sufficient funding at the pilot stage, donors who provide the most funding at this stage are not operationally suited to provide long term funding particularly as m-ARD app providers try to scale up.

\section{METHODOLOGY}

This study used the model of intentions to use mobile services developed by Nysveen et al (2005a) to measure the determinants of farmers' behavioral intentions to use mobile extension service in Assiut governorate. This model consists of 22 items, and asks subjects to respond according to their perceptions on a 5-point Likert-type scale ranging from 1 (strongly disagree) to 5 (strongly agree).

Two districts (EL-Fath and Manfalout) had been randomly selected representing east and west of Assiut governorate respectively. After that, two villages (Awlad Serag and ELGawly) had been randomly selected from the two districts respectively to be the place of this study. To identify the sample size, the study used the table of Krejcie and Morgan (1970) for determining sample size from a given population, as the population of this study is the total number of farmers in the two chosen villages (740 farmers, 236 from Awlad Serag and 504 from EL-Gawly), then the sample size is 254 farmers distributed proportionally on the two villages (81 from Awlad Serag and 173 from EL-Gawly), and they were drawn as simple random sample from farmers of the two selected villages by SPSS. After collecting the data, it cleared up that there are 21 farmers don't have mobile phones; therefore, the study is conducted on 233 farmers who have mobile phones.

Data were collected during the period from August to September 2014 by questionnaire. Data analysis was carried out using SPSS (version15). Frequencies, percentages, mean scores and multiple regression analysis were used for data presentation and analysis. The reliability of the behavioral intentions' model (0.79) was estimated by Cronbach alpha.

\section{RESULTS AND DISCUSSION}

\section{The personal characteristics of the re- spondents}

Table (1) shows the distribution of the respondents according to their personal characteristic, it can be noticed that more than half of respondents (53.7\%) were aged 50 years or more, less than half of them (45.1\%) have education years from 1 to 6 , less than two thirds of them $(60.5 \%)$ work in agriculture on- 
ly, less than half of them $(46.8 \%)$ have families of 8-10 members, more than half of them $(57.5 \%)$ have a farm size less than two feddans, the majority of them $(84.9 \%)$ are members in one local organization (agricultural cooperative) and less than two thirds of them $(65.7 \%)$ have never traveled abroad.

Table 1. Distribution of the respondents according to their personal characteristics $(\mathrm{N}=233)$

\begin{tabular}{|c|c|c|c|}
\hline Characteristics & Category & Frequency & Percentage \\
\hline \multirow{4}{*}{ Age } & $\begin{array}{l}\text { Below } 40 \\
\text { years }\end{array}$ & 26 & 11.1 \\
\hline & $40-$ & 82 & 35.2 \\
\hline & $50-$ & 91 & 39.1 \\
\hline & 60 and above & 34 & 14.6 \\
\hline \multirow{5}{*}{ Education } & Illiterate & 48 & 20.6 \\
\hline & $1-6$ & 105 & 45.1 \\
\hline & $7-9$ & 17 & 7.3 \\
\hline & $10-12$ & 39 & 16.7 \\
\hline & $13-16$ & 24 & 10.3 \\
\hline \multirow[b]{2}{*}{ Profession } & $\begin{array}{l}\text { Agriculture } \\
\text { only }\end{array}$ & 141 & 60.5 \\
\hline & $\begin{array}{l}\text { Agriculture } \\
\text { plus another } \\
\text { profession }\end{array}$ & 92 & 39.5 \\
\hline \multirow{4}{*}{$\begin{array}{l}\text { No. of family } \\
\text { members }\end{array}$} & $2-4$ & 27 & 11.6 \\
\hline & $5-7$ & 82 & 35.2 \\
\hline & $8-10$ & 109 & 46.8 \\
\hline & $11-13$ & 15 & 6.4 \\
\hline \multirow{4}{*}{ Farm size } & $\begin{array}{l}\text { Less than } 1 \\
\text { feddan }\end{array}$ & 73 & 31.3 \\
\hline & $1-$ & 61 & 26.2 \\
\hline & $2-$ & 32 & 13.7 \\
\hline & 3 and above & 67 & 28.8 \\
\hline \multirow[b]{2}{*}{$\begin{array}{l}\text { Membership in } \\
\text { organizations }\end{array}$} & $\begin{array}{l}\text { Member in } \\
\text { one organiza- } \\
\text { tion }\end{array}$ & 198 & 84.9 \\
\hline & $\begin{array}{l}\text { Member in } \\
\text { more than } \\
\text { one organiza- } \\
\text { tion }\end{array}$ & 35 & 15.1 \\
\hline \multirow{3}{*}{$\begin{array}{l}\text { Traveling } \\
\text { abroad }\end{array}$} & $\begin{array}{l}\text { Never trav- } \\
\text { eled before }\end{array}$ & 153 & 65.7 \\
\hline & Below 5 years & 29 & 12.4 \\
\hline & $\begin{array}{l}5 \text { years and } \\
\text { above }\end{array}$ & 51 & 21.9 \\
\hline
\end{tabular}

\section{Farmers' views about mobile extension service}

The respondents were asked three open questions regarding their views about ad- vantages, disadvantages of mobile extension service and their suggestions to make this prospective initiative succeed, Table 2 shows the results. Regarding the advantages of mobile extension service, the respondents mentioned that it can help to get access to agricultural information faster and easier, acquire accurate agricultural information, obtain new agricultural information and it can help as an alternative for the low efficient extension agents. Concerning the possible disadvantages of mobile extension service, the respondents pointed out to the possible costs of the service, the weakness of mobile phone networks, the potential difficulty of dealing with the service and illiteracy of farmers. Respecting farmers' suggestions to make this prospective initiative succeed, the respondents specified different suggestions like: providing the service totally free of charge, subscription to the service by their same phones and SIM cards, offering enough hotlines with enough extension specialists, quick response to farmers' questions and removing SMS's from this service for illiterates. Illiterates (48 farmers) were asked about removing SMS's from this service for them, 17 illiterates $(35.4 \%)$ have suggested removing text messages from this service for them, and 31 illiterates $(64.6 \%)$ reported that they will ask for their relatives' help with the content of the text messages.

\section{Farmers' behavioral intentions to use mobile extension}

Mean scores for the respondents' perceptions of the behavioral intentions model's components are presented in Table 3 . The mean score of the respondents' behavioral intentions to use mobile extension is 7.18 which is $71.8 \%$ of the maximum score (10), this indicates high (positive) intentions to use mobile extension among the respondents, and their prospective behavior proceeds to use mobile extension service if it comes into existence. As displayed in the same table, scores are above average levels of all the six determinants of behavioral intentions. Normative pressure received the highest score among the six determinants $(74.9 \%$ of the maximum score) followed by usefulness (70.6\% of the maximum score); while enjoyment received the lowest score $(52.2 \%$ of the maximum score). 
Table 2. Farmers' views about mobile extension service $(\mathrm{N}=233)$

\begin{tabular}{|c|c|c|}
\hline $\begin{array}{l}\text { Farmers' views about mo- } \\
\text { bile extension service }\end{array}$ & Frequency & $\begin{array}{l}\text { Percent- } \\
\text { age }\end{array}$ \\
\hline \multicolumn{3}{|l|}{ Advantages } \\
\hline $\begin{array}{l}\text { Get access to agricultural } \\
\text { information faster and easier }\end{array}$ & 143 & 61.4 \\
\hline $\begin{array}{l}\text { Acquire accurate agricultural } \\
\text { information }\end{array}$ & 86 & 36.9 \\
\hline $\begin{array}{l}\text { Obtain new agricultural in- } \\
\text { formation }\end{array}$ & 51 & 21.9 \\
\hline $\begin{array}{l}\text { Alternative for the low effi- } \\
\text { cient extension agents } \\
\text { Disadvantages }\end{array}$ & 43 & 18.5 \\
\hline $\begin{array}{l}\text { The possible costs of the } \\
\text { service }\end{array}$ & 128 & 54.9 \\
\hline $\begin{array}{l}\text { The weakness of mobile } \\
\text { phone networks }\end{array}$ & 117 & 50.2 \\
\hline $\begin{array}{l}\text { The potential difficulty of } \\
\text { dealing with the service }\end{array}$ & 104 & 44.6 \\
\hline $\begin{array}{l}\text { Illiteracy } \\
\text { Suggestions }\end{array}$ & 87 & 37.3 \\
\hline $\begin{array}{l}\text { Providing the service totally } \\
\text { free of charge }\end{array}$ & 209 & 89.7 \\
\hline $\begin{array}{l}\text { Subscription to the service } \\
\text { by the same phone and SIM } \\
\text { card }\end{array}$ & 178 & 76.4 \\
\hline $\begin{array}{l}\text { Offering enough hotlines } \\
\text { with enough extension spe- } \\
\text { cialists }\end{array}$ & 113 & 48.5 \\
\hline $\begin{array}{l}\text { Quick response to farmers' } \\
\text { questions }\end{array}$ & 97 & 41.6 \\
\hline $\begin{array}{l}\text { Removing SMS's from this } \\
\text { service for illiterates }\end{array}$ & 32 & 13.7 \\
\hline
\end{tabular}

Table 3. Means of the respondents' perceptions of the behavioral intentions model's components

\begin{tabular}{|clcc|}
\hline No. & $\begin{array}{c}\text { The components of the be- } \\
\text { havioral intentions model }\end{array}$ & Mean & $\begin{array}{c}\text { Maximum } \\
\text { score }\end{array}$ \\
\hline 1 & Perceived expressiveness & 8.22 & 15 \\
2 & Perceived enjoyment & 10.43 & 20 \\
3 & Perceived usefulness & 10.59 & 15 \\
4 & Perceived ease of use & 12.17 & 20 \\
5 & Perceived normative pres- & 11.24 & 15 \\
& sure & & 15 \\
6 & Perceived behavioral con- & 10.36 & \\
& trol & 7.18 & 10 \\
7 & Behavioral intentions & & \\
\hline
\end{tabular}

Source: Questionnaire forms

\section{Farmers' information needs by mobile extension service}

Table 4 presents distribution of the respondents according their information needs by using mobile extension service. It came to clear that the heist percent $(90.9 \%)$ of the respondents are in need of receiving market information (prices, and demand indicators) by mobile phones. It cleared up that $81.1 \%$ of the respondents seek to get the know-how information (what to plant and which seed varieties to use) by mobile phones. The last percent $(45.1 \%)$ of the respondents want to have contextual information (weather, plant protection, best practice for cultivation and inputs) using mobile phones.

Table 4. Distribution of the respondents according to their information needs by using mobile extension service $(\mathrm{N}=233)$

\begin{tabular}{|lcc|}
\hline $\begin{array}{l}\text { Category of infor- } \\
\text { mation }\end{array}$ & $\begin{array}{c}\text { Fre- } \\
\text { quency }\end{array}$ & Percentage \\
\hline $\begin{array}{l}\text { Know-how infor- } \\
\text { mation }\end{array}$ & 189 & 81.1 \\
$\begin{array}{l}\text { Contextual infor- } \\
\text { mation }\end{array}$ & 105 & 45.1 \\
Market information & 212 & 90.9 \\
\hline
\end{tabular}

Source: Questionnaire forms

\section{The effect of the determinants of behav- ioral intentions to use mobile extension}

The study used multiple regression analysis in order to investigate the effect of the six determinants proposed by Nysveen et al (2005a) on farmers' behavioral intentions to use mobile extension. Before performing the multiple regression analysis, a big problem called multicollinearity should be detected. Multicollinearity is a case of multiple regression in which the predictor variables are themselves highly correlated (Paul, 2006). Multicollinearity makes parameter estimates are substantially inflated, making it appear that variables have much stronger effects than they really have. Tolerance and VIF (variance inflation factor) values are good measures for testing multicollinearity. Tolerance and VIF are defined as: 


$$
\text { Tolerance }=1-R^{2} x \text { and VIF }=\frac{1}{\text { Tolerance }}
$$

Where $R^{2} x$ is the coefficient of determination of a regression of $X$ on all other $X$ 's in the model. A tolerance smaller than 0.1 , VIF's greater than 10 suggest that multicollinearity is a problem in one's analysis (Demaris, 2004). Multicollinearity can be fixed by centering independent variables; it is defined as subtracting the mean (a constant) from each score, $\mathrm{X}$, yielding a centered score. Centered variables have low intercorrelation, while uncentered variables have higher intercorrelation, thus higher collinearity. Therefore, it is an important step when testing interaction effects in multiple regression to obtain a meaningful interpretation of results (Robinson and Schumacker, 2009).

Using multiple regression analysis, three important steps (checking multicollinearity, evaluating the model, evaluating each of the independent variables) took place to investigate the effect of the six determinants proposed by Nysveen et al (2005a) on farmers' behavioral intentions to use mobile extension service. Tolerance and VIF measures were calculated for checking multicollinearity. Table 5 shows that either tolerance or VIF values in this study are within the above mentioned ranges. This indicates that the data do not suffer any multicollinearity problems. So, there's no need for centering independent variables.

Table 5. Tolerance and VIF measures testing multicollinearity in the study data

\begin{tabular}{|lcc|}
\hline Variables & Tolerance & VIF \\
\hline Expressiveness & .789 & 1.267 \\
Enjoyment & .973 & 1.028 \\
Usefulness & .753 & 1.328 \\
Ease of use & .652 & 1.533 \\
Normative pressure & .529 & 1.890 \\
Behavioral control & .567 & 1.764 \\
\hline
\end{tabular}

Source: Questionnaire forms

Next, concerning the evaluation of the model as a whole, table 6 shows that the model of Nysveen et al (2005a) is overall significant $(F=88.24, p<.001)$; behavioral intentions is predicted well from expressive- ness, enjoyment, usefulness, ease of use, normative pressure and behavioral control. $\mathrm{R}^{2}$ is 0.71 , which means that the model, or the six determinants of behavioral intentions, significantly explains $71 \%$ of variance in farmers' behavioral intentions to use mobile extension service.

The last step is related to evaluating the contribution of each independent variable to explain the dependent variable. To compare the different variables' effect, it is important to look at the standardized coefficients $(\beta)$, not the unstandardized ones (B). Standardizing means that these values for each of the different variables have been converted to the same scale so that it can be compared. If the aim of the study is constructing a regression equation, the unstandardized coefficients should be used (Pallant, 2007). In this case, this study is interested in comparing the contribution of each independent variable; therefore the beta values will be used. Table 6 shows that perceived behavioral control has the largest coefficient $(\beta=.430, p<.001)$, followed by perceived ease of use $(\beta=.248$, $p<.001)$, perceived usefulness $(\beta=.198$, $p<.001)$, perceived normative pressure $(\beta=.122, \quad p<.05)$ and perceived expressiveness $(\beta=.104, p<.05)$. The same table revealed that the effect of perceived enjoyment on behavioral intentions is not significant $(\beta=.063, p>.05)$.

Table 6. Multiple regression analysis of the variables predicting behavioral intentions to use mobile extension service

\begin{tabular}{|lccc|}
\hline Variables & $\beta$ & $\mathrm{t}$ & Sig. \\
\hline Expressiveness & .104 & 2.486 & .014 \\
Enjoyment & .063 & 1.697 & .091 \\
Usefulness & .198 & 4.833 & .000 \\
Ease of use & .248 & 5.502 & .000 \\
Normative pressure & .122 & 2.429 & .016 \\
Behavioral control & .430 & 8.906 & .000 \\
\hline
\end{tabular}

Source: Questionnaire forms

Note: $R^{2}=0.71, F=88.24, p<.001$

\section{CONCLUSION}

The results of this study offer several recommendations for the potential producers of 
mobile extension service when developing the prospective mobile extension service. It is important for the potential producers of mobile extension service to be aware of the opportunities and resources (behavioral control) that are available for farmers when they develop the service. So, according to the views of the respondents, mobile extension service should be free of any charges, designed on the basis that farmers will keep their own mobile phones and SIM cards, offering enough hotlines with enough extension specialists and response to farmers' questions as soon as possible.

The potential producers of mobile extension service should consider the importance of the service easiness especially for illiterates by receiving farmers' questions through direct calls to several hotlines and sending agricultural information to farmers by SMS's. Service usefulness is proved to be an important variable predicting farmers' prospective use of mobile extension service, the presented content should be accurate, new and advantageous compared to what they already know. The prospective content should also meet the information needs of farmers related to market information (prices, and demand indicators) and know-how information (what to plant and which seed varieties to use). For the purpose of spreading the diffusion of the potential mobile extension service, the potential producers can depend on normative pressure through social networks of farmers like relatives, neighbors and local leaders.

In a previous study, Abdelghany (2014) have studied mobile extension as a potential organizational change from the perspective of extension employees in the New Valley governorate, it came out that the respondents are ready for implementing the mobile extension initiative, they have the adherent beliefs for this change, and their support to the change are greater than their resistance to it. By integrating the results of the current study and the results of the previous study, the potential producers of mobile extension service must catch this opportunity of the positive intentions of farmers and the readiness of employees to start performing this initiative practically taking into account the results of these studies.

\section{REFERENCES}

Abdelghany, M. 2014. Readiness for change, change beliefs and resistance to change of extension personnel in the New Valley governorate about mobile extension. Annals of Agricultural Sciences, 59 (2): 297-303.

Aker, J. 2011. Dial "A" for Agriculture: A review of information and communication technologies for agricultural extension in developing countries, CGD Working Paper No. 269, Center for Global Development, Washington, D.C. Available at: http://www.cgdev.org/sites/default/files/142549 7 file Aker A for Agriculture FINAL.pdf

Brugger, F. 2011. Mobile applications in agriculture, Syngenta Foundation, Basel, Switzerland. Available at:

http://www.syngentafoundation.org/temp/Repor $t$ on mAgriculture abridged web version.pdf

Central Administration for Agricultural Extension 2011. Mobile agricultural extension, Egypt (in Arabic). Available at: http://caae-eg.com/index.php/ask-answer/ 156.html

Davis, F. 1989. Perceived usefulness, perceived ease of use, and user acceptance of information technology, MIS Quarterly, 13 (3):319-340. Available at:

http://iris.nyit.edu/ kkhoo/Spring2008/Topics/T AM/PercieveUsefulness MIS.pdf

Demaris, A. 2004. Regression with social data, John Wiley \& Sons, Inc., Hoboken, New Jersey, USA.

Fielding, M. and Ninsiima, D. 2012. From motorbike to mobile phone: New extension services for rural farmers through mobile ICT, Swedish International Agricultural Network Initiative, Discussion Brief No.1. Available at:

http://www.sei-international.org/mediamanager/ documents/Publications/SEl-DiscussionBriefSIANI-ICTandAfricanFarmers-2012.pdf

Fu, X. and Akter, S. 2011. The impact of ICT on agricultural extension services delivery: evidence from the rural e-services project in India, TMD Working Paper Series No. 046, University of Oxford, Department of International Development. Available at: http://www3.qeh.ox.ac.uk/pdf/ptmd/SLPTM D-WP-046.pdf

Krejcie, R. and Morgan, D. 1970. Determining sample size for research activities, 
Educational and Psychological Measurement, 30: 607-610. Available at: https://opa.uprrp.edu/InvInsDocs/KrejcieandMo rgan.pdf

Malhotra, N. and McCort, J. 2007. A crosscultural comparison of behavioral intention models. International Marketing Review, 18(3):235-269. Available at:

http://km.camt.cmu.ac.th/phdkm/2007 $2 \mathrm{CW} / \mathrm{yi}$ ngrudi/5\%20Thesis\%20Proposal\%20Examinati on\%20Slides\%20and\%20Proposal/a crosscultural classification.pdf

Mittal, S., Gandhi, S. and Tripathi, G. 2010. Socio-economic impact of mobile phones on Indian agriculture, Working Paper No. 246, Indian Council for Research on International Economic Relations. Available at: http://icrier.org/pdf/Working Paper246.pdf

Nysveen, H., Pedersen, P. and Thorbjørnsen, H. 2005a. Intentions to use mobile services: Determinants and cross- service comparisons. Journal of the Academy of Marketing Science, 33(3): 330-346. Available at: http://download.springer.com/ statc/pdf/620/art\%253A10.1177\%252F0092070 305276149.pdf?auth66=1415013382 ac07e73 fcd0d65d8476bd9b37567a310\&ext=.pdf

Nysveen, H., Pedersen, P. and Thorbjørnsen, H. 2005b. Explaining intention to use mobile chat services: Moderating effects of gender. Journal of Consumer Marketing, 22(5): 247-256. Available at: http://www.emeraldinsight.com/doi/pdfplus/10.1 108/07363760510611671

Pallant, J. 2007. SPSS survival manual, third edition, Open University Press, England.

Paul, R. 2006. Multicollinearity: Causes, effects and remedies, Indian Agricultural Statistics Research Institute, New Delhi. Available at: http://www.iasri.res.in/ seminar/AS-299/ebooks\%5C2005-2006\%5CMsc \%5Ctrim2\%5C3.\%20Multicollinearity-20 Causes,Effects\%20and\%20Remedies-Ranjit.pdf

Punnoose, A. 2012. Determinants of intention to use E-learning based on the technology acceptance model. Journal of Information Technology Education Research, 11: 301-337. Available at: http://www.jite.org/documents/Vol11/JITEv11p3 01-337Punnoose1197.pdf

Pye-Smith, C. 2012. Agricultural extension, a time for change, Technical Centre for Agricultural and Rural Cooperation, The
Netherlands. Available at:

http://publications.cta.int/media/publications/do wnloads/1689 PDF.pdf

Qiang, C., Kuek, S., Dymond, A. and Esselaar, S. 2012. Mobile applications for agriculture and rural development, ICT Sector Unit, the World Bank, Washington, D.C. Available at:

http://media.kiva.org/labs/mobile/2012 Mobile Applica-

tions for Agriculture and Rural Development. pdf

Robinson, C. and Schumacker, R. 2009. Interaction effects: Centering, variance inflation factor, and interpretation issues, Multiple Linear Regression Viewpoints, 35(1): 6-11. Available at:

http://mlrv.ua.edu/2009/vol35 1/robinson schu macke rproof.pdf

Sendecka, L. 2006. Adoption of mobile services: Moderating effects of service's information intensity, Master Thesis, Norwegian School of Economics and Business Administration. Available at: http://brage.bibys.no/xmlui/bitstream/handle/11 250/167783/thesis.pdf?sequence $=1$

The World Bank 2011. ICT in agriculture, connecting smallholders to knowledge, networks, and institutions, Report Number 64605, Washington, DC. Available at: http://www.ictinagriculture.org/sites/ictinagriculu re.org/files/final book ict agriculture.pdf

Venkatesh, V. and Davis, F. 2000. A theoretical extension of the technology acceptance model: Four longitudinal field studies. Management Science 46 (2): 186-204. Available at:

http://vvenkatesh.us/Downloads/Papers/fulltext/ pdf/2000(2) MS Venkatesh Davis.pdf

Vodafone Egypt. 2011. Vodafone launches agricultural guidance services via mobile. Available at:

http://www.vodafone.com.eg/vodafoneportaleb/ en/releaseDetail Page?dDocName=VF 01793 $\underline{9}$

Wong, K., Osman, R., Choo, P. and Rahmat, M. 2013. Understanding student teachers' behavioral intention to use technology: Technology acceptance model (TAM) validation and testing, International Journal of Instruction, 6(1): 89-104. Available at:

http://files.eric.ed.gov/fulltext/ED539841.pdf 